\title{
Climatic Characteristics Indicated by some Landscapes Methods in Indirect Climatology
}

Taiji Yazawa

Even in a country where intensive climatic observation-net covers whole the country, it is not always possible to make clear the climatic characteristics in any region in meso- and local climatic scale by the climatic data. This is an obstacle to the investigation of meso- and local climatology. Phenological phenomena, however, as is general known, help to interpret climatic characteristics as well as climatic regionalities. The author made some reports on the phenological phenomena of some regions of Japan from the viewpoint of local climatology 1 . In addition, expecting that some characteristics observed on landscapes may be used as the climatc indicators, he made field surveys for many years mainly in Japan. The author's hope is to widen the bottleneck in the investigation of meso- and local climatology. The author tried to check whether the climatic features presumed by analysis of landscapes could be proved to be well-grounded by the climatic data or the results of the climatic observations. As the result the author found that there are many good examples in landscapes and to observe or to analyze the landscapes themselves should be very useful for meso- and local climatological investigation ${ }^{1}$. The author's method is to climatology what indirect aerology is to aerology. Thus, his method could be called indirect climatology.

\section{Indirect climatology regarding windsystems}

Methods in indirect climatology are especially useful to make clear the regionalities of winds. Some geographers in Japan as well as the author have had good evidences that the distribution of the deformed crown, especially the degree of deformation, indicate the distribution of prevailing winds, as is well known in many countries. Furthermore, the author is interested in the windbreaks observed all over Japan and studied their distribution from the standpoint of indirect climatology. As the result he could evaluate their power of expression as an indicator regarding strong wind systems. Followings are some examples found in Japan.

On the upper and middle stream of Ina Valley along the Tenryû (one of the largest rivers in Japan) in central Japan which extends north to south between the Japanese Alps, the broad flood plain and river terraces are dotted with extremly flat houses, almost all of them are furnished with windbreaks (mainly Cryptomeria japonica) on the south side. Moreover, the south side of the houses is mostly closed by wall, rarely with small windows. In general regions the south side of houses in Japan is opened to the sun, and designed to ventilate the monsoon winds in muggy summer, the north or west side, on the other hand, is closed to freezing northwestern or northern monsoon in cold season. In view of such generality the settlement pattern of region stated above is no doubt rare case. It is sure that biting southerly winds should prevail there in winter.

By analyzing the weather in winter in detail the author found that in winter when the monsoon blows violently all over Japan, the topographic occlusion happens in this region which lies behind the high mountains of ca. $3000 \mathrm{~m}$ class of the Japanese Alps. Northwest winds, after crossing the windgap to the southwest of this region, are then deflected to southerly and are whistling in this region as freezing south winds. They are so severe that sensible temperature falls considerably and daily life is very hard if no windbreak protect the houses from the stormy south winds. The above-mentioned housetype and structure is also good enough for preventing the stormy southwinds. Thus characteristics of the settlement show the climatic characteristics overthere ${ }^{1}$. The observation of settlement pattern of this region led to finding of topographic occlusion.

On the Pacafic side, especially in northern and central Japan, distribution of windbreaks show remarkable regionalities. By analyzing the distribution the authour found the fallwind-systems, especially the divergent windsystems on the leeward of winter monsoon in mesoclimatic scale, for instance in Kanto, Tokai and southern part of Tohoku district. The author also found some zones in such districts, in which the winter monsoon especially develops topographically.

Due to the frequent invasions of typhoon in summer and automn ${ }^{5}$ and the bitter monsoon in winter, southwest Japan, especially isolated island groups is characterized by stormy winds. Dense windbreaks and strong stone walls run round the houses and mostly all houses are hidden in woods. By analyzing such landscapes in detail and weather data, the author succeeded in an attempt to make clear the topographic effects on winds and their regionalities, 
for instance regional differences between the east and the west coast in Amami Island Group in southwestern Japan ${ }^{3}$. Similar landscapes could be seen also in Izu Island Group in southeastern Japan ${ }^{6}$.

On the Japan Sea side where in winter snow is frequently driven by strong winds (mainly by monsoon winds) snow fences settled temporary to the windward of houses are indispensable to protect daily life from snowdrift. By surveying the distribution of such fences the author found the influence of local topography to the windsystems in snowy weather in meso- and local climatic scale. A good example could be found on the Noto Peninsula, the largest peninsula on the coast of the Japan Sea, where great difference could be pointed out between outer and inner Noto. Even only low hilly land of ca. $300 \mathrm{~m}$ class between them is effective to prevent snowy winds on the leeward of the peninsula?

On the atrio of Mt. Miharayama in Oshima, a volcanic island of the Fuji Volcanio Zone, the author found the characteristic local windsystem caused by the topography of the somma. In this case the distribution of wind-eroded pebbles is very significant $^{4}$.

\section{An example observed on land-utilization}

In rural region where land utilization is intensive special regards are often paid to the climatic conditions. As the result there are many examples to indicate the effectiveness of the methods in indirect climatology. An example could be seen on mulberry fields which before the War were predominated in many fields. As mulberry leaves suffer serious damage from the last killing frosts, special attention is paid from farmer's experience rather than by modern scientific investigations to the climatic conditions, especially distribution of nocturnal temperature, cold air lakes or frost holes ${ }^{1}$. There are many good examples for indirect climatology on mulberry fields, for example regional differences of the way of cultivation and standard locations of mulberry fields themselves, having regard to the distribution of cold air lakes, frost holes or killing frosts in detail. Good examples could be pointed out in Ina, Suwa and Matsumoto Basin in mountainous region in central Japan.

\section{House structure as climatic indicator}

Some house structures indicate often climatic characteristics of the region. The author analyzed climatic regional characteristics in some basins in central Japan from the viewpoint of indirect climatology. On the basis of the distribution of Parmeria conceperse on the roofs of houses he made clear the distribution of temperature-humidity complex, in Saku Basin in central Japan.

On the deeply snow-covered regions on the Japan Sea side houses have small dormer-windows. In general the deeper is the snow depth, the higher is the heights of dormer-windows. The author investigated the distribution of such heights in Akita Prefecture in northern Japan and concluded that they indicate the distribution of the mean deepest snowdepth on the whole.

In the windy regions in central Japan many houses with wind-proof structure could be found.

\section{Indicator of humidity distribution}

It is often found that distribution of some special plants itself indicate the climatic regionalities. For instance, distribution of the growth of Usnea longissima indicates as a whole the distribution of humidity. A good example was found in the valleys along the Fuji, one of the largest rivers of Japan, in central Japan.

\section{Conclusion}

The author introduced some results of his works obtained by the methods in indirect climatology. As above-mentioned the author did not jump into a hasty conclusion if observation results can not be corraborated by the climatic data. The object of his method is to make clear the generalized distribution of some characteristics as the first step, and then he tries to corraborate them by any climatic data.

The role of indirect climatology should be an introduction to meso- and local climatological investigations in the fields.

In recent years, however, particularly after the War, many typical indicators for indirect climatology have been disappearing, due to the rapid changes of style of living and land-utilization in Japan.

\section{References}

1 Yazawa T., 1953: Kiko Keikan (Climatic landscapes). In Japanese, 228 p.

2 - 1955: Climatological Survey in the Noto Peninsula. In: "Noto». In Japanese, 12-21.

3 - 1959: Climatic observations of Amami Island Group. In: «Amami». In Japanese, 62-81. 
4 - 1959: Climatic landscapes in Japan. Proc. IGU Reg. Conf., in Japan 1957, 237-240.

5 - 1960: Witterung und Klima im äußersten Süden und Südwesten Japans und ihre Bedeutung für den Reisbau. Jap. Jour. Geol. Geogr. 31, 261271.

6 - 1968: Weather climatalogy of the Izu Island Group, southeastern Japan. Geogr. Reps. Tokyo Metrop. Uni. 3, 97-106.

Klima-Charakteristika angezeigt durch Landschaftselemente - Methoden der indirekten Klimatologie

Untersuchungen des Meso- und Lokalklimas lassen sich nicht immer allein aus Klimadaten ermitteln.
Der Autor unternahm daher ausgedehnte Feldstudien in Japan, um den Wert bestimmter Landschaftselemente als Indikatoren für Klimamerkmale zu überprüfen. Eine Landschaftsanalyse erscheint für meso- und lokalklimatische Differenzierungen sehr aufschlußreich. Diese Methode wird als indirekte Klimatologie bezeichnet.

Als Anzeiger für regionale Windsysteme dienen Art und Verteilung der Baumkronenverformung, Windschutzstreifen, Schneezäune usw. Die Landnutzung spiegelt oft klimatische Besonderheiten exakt wieder, z. B. die Maulbeerbäume. Weitere Hinweise ergeben sich aus der Hauskonstruktion, wie z. B. der Orientierung des Hauses, Größe und Anordnung der Fenster usw. Leider verschwinden viele dieser typischen lokalen Indikatoren infolge der raschen Landschaftsveränderungen. 